\title{
Implications of Irrigation Method and Amount of Water Application on Phytophthora and Pythium Infection and Severity of Root Rot in Highbush Blueberry
}

\author{
David R. Bryla ${ }^{1}$ and Robert G. Linderman \\ U.S. Department of Agriculture, Agricultural Research Service, \\ Horticultural Crops Research Unit, 3420 NW Orchard Avenue, Corvallis, \\ OR 97330
}

Additional index words. Vaccinium corymbosum, evapotranspiration, microirrigation, root system vigor, soil water content

\begin{abstract}
A 2-year study was done in Oregon to determine the effects of irrigation method and level of water application on the development of root rot in northern highbush blueberry (Vaccinium corymbosum L. 'Duke'). Plants were grown on mulched, raised beds and irrigated by overhead sprinklers, microsprays, or drip at $50 \%, 100 \%$, and $150 \%$ of the estimated crop evapotranspiration requirement. Soil at the site was a silty clay loam. By the end of the first season, plants were largest with drip, intermediate-sized with microsprays and smallest with sprinklers; however, this was not the case the next season. By the end of year 2, plants irrigated by drip had less canopy cover, fewer new canes, lower pruning weights, and only half the shoot and root dry weight as plants irrigated by sprinklers or microsprays. Destructive sampling revealed that the field was infested by root rot. Less growth with drip was association with higher levels of infection by the root pathogen, Phytophthora cinnamomi. Phytophthora infection increased with water application, regardless of irrigation method, but averaged $14 \%$ with drip and only $\mathbf{7 \%}$ with sprinklers and microsprays. Roots were also infected by Pythium spp. Pythium infection likewise increased with the total amount of water applied but, unlike $P$. cinnamomi, was similar among irrigation methods. Overall, drip irrigation maintained higher soil water content near the base of the plants than sprinklers and microsprays, resulting in conditions more favorable to root rot. Sprinklers and microsprays may be better alternatives than drip at sites prone to problems with the disease.
\end{abstract}

Root rot is a prevalent disease of highbush blueberry (Vaccinium spp.). Symptoms include reduced plant vigor, yellowing and premature reddening of leaves, and early defoliation of green stems (Cline and Schilder, 2006). Affected plants are often poorly rooted and easy to pull out of the soil. Tip dieback and plant death may occur in

\footnotetext{
Received for publication 16 Apr. 2007. Accepted for publication 21 May 2007.

Financial support was provided by the Northwest Center for Small Fruits Research.

Mention of trademark, proprietary product, or vendor does not constitute a guarantee or warranty of the product by the U.S. Dept. of Agriculture and does not imply its approval to the exclusion of other products or vendors that also may be suitable.

We thank H. Rempel, W. Fummerton, R. Moes, A. Shireman, and N. Rivard for technical assistance throughout the project. We also thank J. Gartung and R. Sefton for help on irrigation system design and installation; A. Davis for help on media plating and pathogen identification; and D. Brazelton, B. Strik, and W. Yang for useful discussions on the project.

${ }^{1}$ To whom reprint requests should be addressed; e-mail brylad@onid.orst.edu.
}

tion (Café-Filho and Duniway, 1995; CaféFilho et al., 1995; Ristaino et al., 1988). Higher frequencies of drip irrigation increased levels of root rot incited by $P$. capsici Leonian in pepper (Capsicum annuum L.) (Ristaino, 1991). Identifying proper placement and frequency of water applications is useful when developing strategies for managing soilborne pathogens such as Phytophthora and Pythium.

Not surprisingly, irrigation effects on disease development often differ among irrigation methods. For example, localized systems such as drip, which apply water to only a small fraction of the soil, often increase root rot when disease pressure is high and irrigation is overapplied (Feld et al., 1990). Sprinkler systems, on the other hand, potentially increase dispersal of soil pathogens by splashing (Ristaino and Johnson, 1999) as well as increase the spread of fruit and foliar diseases (Schlub, 1983), but also tend to reduce sporangia formation and lower potential for zoospore release by distributing water more evenly (Berhardt and Grogan, 1982; Duniway, 1983). Utkhede and Smith (1996) found in apple (Malus domestica Borkh.) that crown and root rot incited by $P$. cactorum (Lebert and Cohn) J. Schröt. was most severe when trees were irrigated by microsprays and similar when trees were irrigated by sprinklers and drip. Clearly, pathogenic responses to irrigation application may vary depending on the crop, site conditions, and the type of cultural practices used.

In blueberry, little information is available on the impacts of irrigation on root rot and almost nothing is known about how the disease is affected by different methods and levels of irrigation (de Silva et al., 1999). Blueberry often requires irrigation for profitable production and most fields are irrigated by either sprinklers or drip (Strik and Yarborough, 2005). Low-volume microsprays are also used on occasion but are much less common as a result of difficulties with plant interference during water application (Holzapfel et al., 2004; Patten et al., 1989).

The objective of the present study was to determine the effects of sprinkler, microspray, and drip irrigation systems on the incidence and severity of root rot in highbush blueberry. We also determined the effects of irrigation level on root rot by applying three different amounts of water over the growing season with each system. Information gained by the study will help identify irrigation practices that reduce the risks of developing root rot during field establishment.

\section{Materials and Methods}

The study was conducted at the Oregon State University Lewis-Brown Horticultural Research Farm in Corvallis, OR, in a field of 'Duke' northern highbush blueberry. The field was planted in Apr. 2004 at a site previously planted in 2003 with a cover crop of rye grain (Secale cereale L.) and common vetch (Vicia sativa L.) and never planted before with blueberry. Plants were obtained 
from a commercial nursery (as 2-year-old container stock) and spaced $0.76 \times 3.05 \mathrm{~m}$ apart on raised beds (0.4-m high and 0.9-m wide). Soil at the site was a Malabon silty clay loam (fine, mixed, superactive, mesic Pachic Ultic Argixerolls) adjusted to $\mathrm{pH} 5.5$ with two applications of $670 \mathrm{~kg} \cdot \mathrm{ha}^{-1}$ of elemental $\mathrm{S}$ incorporated 6 and 10 months before planting. Five centimeters of Douglas fir (Pseudotsuga menziesii Franco) sawdust was also incorporated (within the plant row) $\approx 1$ month before planting and an additional $5 \mathrm{~cm}$ was applied on top of the beds immediately after planting. Grass alleyways (1.1-m wide) were planted and maintained between the beds. Ammonium sulfate fertilizer was banded beneath the canopy each spring (in split applications in April, May, and June) at a rate of $66 \mathrm{~kg} \cdot \mathrm{ha}^{-1}$ of $\mathrm{N}$ during the first year after planting and $90 \mathrm{~kg} \cdot \mathrm{ha}^{-1}$ of $\mathrm{N}$ thereafter. Plants were irrigated as needed with hand-set sprinklers for 3 months before irrigation treatments were initiated in July 2004.

Irrigation treatments were arranged in a split-plot design and included three irrigation systems (overhead sprinkler, microspray, and drip) as main plots and three irrigation levels $[50 \%, 100 \%$, and $150 \%$ of the estimated crop evapotranspiration requirements $\left.\left(\mathrm{ET}_{\mathrm{c}}\right)\right]$ as subplots. Each treatment subplot consisted of three rows of eight plants and was replicated five times. Overhead sprinkler treatments were irrigated by four sprinklers per subplot; a $5.7-\mathrm{L} \cdot \mathrm{min}^{-1}$ rotor sprinkler (model 32SA; Rain Bird Corp., Glendora, CA) was located on each corner of the subplots and set to rotate in $\mathrm{a} \approx 6-\mathrm{m}$ radius $90^{\circ}$ wetting pattern at operating pressures of 170 to $210 \mathrm{kPa}$. Microspray treatments were irrigated with 22.7 L $\cdot \mathrm{h}^{-1}$ hanging fan-jet microsprinklers (DC Series; Bowsmith, Exeter, CA) located between every other plant and suspended on a trellis wire $\approx 1.2 \mathrm{~m}$ above the plants. The fanjet emitters had a 2.7 - to $3.0-\mathrm{m}$ diameter circular wetting pattern at operating pressures of 100 to $140 \mathrm{kPa}$. Drip treatments were irrigated by drip tubing (GeoFlow, Charlotte, NC) placed along the top of the planting bed near the base of the plants. The tubing had $1.9 \mathrm{~L} \cdot \mathrm{h}^{-1}$ pressure-compensating, in-line emitters spaced $0.30 \mathrm{~m}$ apart. Overhead sprinkler treatments were irrigated twice per week, as needed, whereas microspray and drip treatments were irrigated three times per week. Irrigation water was pumped from a well and water applications were controlled in each treatment by electric solenoid valves and an automatic timer set weekly. Sprinklers and microsprays were always set to run between 0000 and $0600 \mathrm{HR}$ to minimize problems with wind drift between adjacent treatments. There was no evidence of water runoff from any treatment.

Precipitation, air temperature, and $\mathrm{ET}_{\mathrm{c}}$ were obtained at least weekly from a Pacific Northwest Cooperative Agricultural Weather Network AgriMet weather station (http:// usbr.gov/pn/agrimet/). The station was located less than $0.25 \mathrm{~km}$ from the field site. Evapotranspiration estimates were adjusted for plant size and irrigation system efficiency in each treatment following procedures outlined in Holzapfel et al. (2004). Water applications were measured using turbine water meters (Sensus Metering Systems, Uniontown, PA) installed at the inflow of each irrigation system. The total amount of water applied to each treatment during the first two growing season is shown in Table 1.

Soil water content was measured monthly (June to August) in the top $0.3 \mathrm{~m}$ of the plant bed using a Trase I time domain reflectometry system (Soilmoisture Equipment Corp., Santa Barbara, CA). The system was equipped with a pair of $0.3-\mathrm{m}$ stainless steel waveguides and a waveguide connector. The waveguides were installed vertically at two locations in the middle of the center row of each plot $\approx 0.15 \mathrm{~m}$ from two representative plants per plot.

Canopy cover was estimated on 21 Apr., 24 June, 21 July, 16 Aug., and 20 Sept. 2005 from digital images captured using an ADC multispectral camera (TetraCam, Chatsworth, CA). The camera was suspended from a marked trellis wire located $\approx 2.5 \mathrm{~m}$ above the middle bed. Images were collected on each date from every other plant of the center six plants in each plot for a total of 135 images per date. Percent live cover in each image was determined using software (Pixelwrench and Briv32) provided by the camera manufacturer. Care was taken to ensure that image area always exceeded canopy width of each image. Any cover by weeds or the grass alleyway was cleaned from the images using Adobe Photoshop v. 5.0 (Adobe Systems, San Jose, CA) before analysis. Live cover was converted to total percent canopy cover based on the proportion of the field covered by each image.

Whip counts and fresh pruning weights were collected from the middle six plants of each plot on 29 Jan. to 15 Feb. 2005 and 23 to 25 Jan. 2006. Three plants per plot were also destructively harvested in Oct. 2005; the plants were randomly selected from border rows of each plot. To harvest the plants, soil was first cut around them using a flat shovel. Cuts were made on each side of the plant, both parallel and perpendicular to the row, at $\approx 0.4 \mathrm{~m}$ from the crown. Plants were then pulled up by their base and rated for root system vigor. Ratings included: $1=$ very weak (little to no roots beyond the original root ball); 2 = weak (some new roots beyond the original root ball but relatively poor root development); 3 = medium (good root development but plant pulled easily from soil without a shovel); $4=$ strong (required a shovel to remove plant from soil); and $5=$ very strong (large, well-developed root system). When plants were removed by shovel, soil was also cut at $\approx 0.3 \mathrm{~m}$ below the surface. Few roots were found deeper than $0.3 \mathrm{~m}$, which is typical for blueberry (Bryla and Strik, 2007).

After harvest, plants were divided into shoots (canes only; many leaves had already senesced) and roots and washed. Approximately $100 \mathrm{~g}$ of the fine roots (selected from all areas of the root system) from each plant was surface-sterilized in a $2 \%$ sodium hypochlorite solution for $3 \mathrm{~min}$, rinsed with $\mathrm{dH}_{2} \mathrm{O}$, and blotted dry on paper towel. Individual roots were then randomly chosen from the sample, cut into $\approx 6-\mathrm{mm}$ segments, and direct-plated onto petri dishes filled with either $\mathrm{P}_{5} \mathrm{ARP}$ agar (Kannwischer and Mitchell, 1978), which is selective for members of the family Pythiaceae, or $\mathrm{P}_{5} \mathrm{ARP}$ agar amended with $25 \mathrm{ppm}$ hymexazol $\left(\mathrm{P}_{5} \mathrm{ARP}+\mathrm{H}\right.$; Tachigaren, $70 \%$ a.i.; Saankyo Co., Tokyo), which is selective for Phytophthora spp. (Masago et al., 1977). Five root segments from each plant were placed on four plates of each medium for a total of 40 root segments per plant. The plates were incubated in the dark at $20{ }^{\circ} \mathrm{C}$ and then examined daily for pythiaceous colony growth for at least $7 \mathrm{~d}$. Percent root infection was calculated based on the number of root segments colonized per plant. Pythium isolates were identified to genus only, but Phytophthora isolates were identified to species. Species identification was done at $10 \times$ to $40 \times$ magnification and was based on morphological characteristics of sexual and asexual structures observed in the isolates (Stamps et al., 1990). Shoots and remaining roots from each plant were oven-dried at $70{ }^{\circ} \mathrm{C}$ and weighed.

Plant-free soil samples and irrigation water were collected and tested at the Oregon State Univ. Plant Clinic for Phytophthora and Pythium on 5 June 2006. For soil testing, the field was divided into five sections, with seven rows per section, and sampled in a Z-pattern. Five soil cores (5-cm diameter $\times$ $30-\mathrm{cm}$ deep) were randomly collected from each section, always just outside the grass alleyway (i.e., in grass-free soil), and combined and homogenized; a 100-g subsample was then covered with $\mathrm{dH}_{2} \mathrm{O}$ and baited for $48 \mathrm{~h}$ with leaf discs of Rhododendron $\times$ PJM and Camellia sasanqua Thunb. For water testing, three 1-L samples were collected near the well head at 1 and $60 \mathrm{~min}$ after

Table 1. Total irrigation water applied to 'Duke' blueberry in 2004 and 2005.

\begin{tabular}{|c|c|c|c|c|c|c|}
\hline \multirow[b]{3}{*}{ Irrigation level } & \multicolumn{6}{|c|}{ Irrigation $(\mathrm{mm})^{\mathrm{z}}$} \\
\hline & \multicolumn{3}{|c|}{2004} & \multicolumn{3}{|c|}{2005} \\
\hline & Sprinkler & Microspray & $\overline{\text { Drip }}$ & Sprinkler & Microspray & $\overline{\text { Drip }}$ \\
\hline $50 \% \mathrm{ET}_{\mathrm{c}}$ & 183 & 114 & 97 & 470 & 208 & 175 \\
\hline $100 \% \mathrm{ET}_{\mathrm{c}}$ & 366 & 229 & 190 & 826 & 429 & 358 \\
\hline $150 \% \mathrm{ET}_{\mathrm{c}}$ & 546 & 340 & 272 & 1242 & 632 & 493 \\
\hline
\end{tabular}

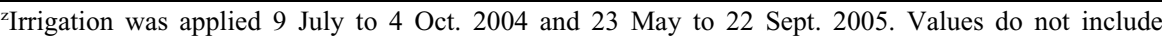
precipitation.

$\mathrm{ET}_{\mathrm{c}}=$ estimated crop evapotranspiration. 
turning on the pump; samples were agitated and vacuumed $(100-\mathrm{mL}$ aliquot) through sterile $47-\mathrm{mm}$ diameter nitrocellulose filters with $5-\mu \mathrm{m}$ pores. Leaf discs and filters were each plated onto $\mathrm{P}_{5} \mathrm{ARP}+\mathrm{H}$ media and examined for Phytophthora and Pythium as described.

Statistical analysis. Data were analyzed by split-plot analysis of variance using SAS v. 9.1 (SAS Institute, Cary, NC) with irrigation system treated as the main plot effect and irrigation level treated as the subplot effect. Time was also included with multiobservational data (i.e., soil water content and canopy cover) and treated as a subsubplot effect (Gomez and Gomez, 1984). Soil water content was unaffected by time each year $(P>$ 0.05 ) and therefore the monthly readings were pooled over time. Canopy cover and percent root infection data were log and arc sine transformed, respectively, before analysis, and back-transformed for presentation. Comparisons among irrigation system means were performed at the 0.05 level using Fisher's protected least significance difference $\left(\mathrm{LSD}_{0.05}\right)$ test or Duncan's multiple range test (transformed data). Response to irrigation levels was determined using orthogonal polynomials. Regression analysis was done to determine relationships among plant dry weight, root system vigor, and the percentage of root fragments infected by Phytophthora and Pythium using SigmaPlot v. 8.0 (SPSS, Chicago).

Only one significant interaction was found in the study: a system $\times$ time interaction on canopy cover $\left(F_{2,24}=25.13, P<\right.$ $0.05)$. All other data are presented in tables (irrigation system) and figures (irrigation level) as significant main effects $(P \leq 0.05)$.

\section{Results and Discussion}

To adjust for differences in plant size and application efficiency, $\approx 89 \%$ to $169 \%$ more water was applied by sprinkler and $18 \%$ to $28 \%$ more water was applied by microspray than by drip (Table 1). Effective rainfall (April to September) contributed an additional $216 \mathrm{~mm}$ of water to each treatment in 2004 and $244 \mathrm{~mm}$ in 2005 ( $\approx 30 \%$ to $40 \%$ of which deep percolated below the roots each year). June, July, and August were the warmest and driest months with average daily high temperatures of 21 to $29^{\circ} \mathrm{C}$ and precipitation less than $10 \%$ of the annual total of $890 \mathrm{~mm}$ in 2004 and $1001 \mathrm{~mm}$ in 2005. Estimated water requirements for plants irrigated at $100 \% \mathrm{ET}_{\mathrm{c}}$ by sprinkler, microspray, and drip were 366,229 , and $190 \mathrm{~mm} \cdot \mathrm{y}^{-1}$, respectively, in 2004, and 826, 429, and $358 \mathrm{~mm} \cdot \mathrm{y}^{-1}$, respectively, in 2005 . These amounts were $\approx 6 \%$ to $27 \%$ less, depending on year and irrigation system, than those required by young 'Elliott' blueberries grown at the site (Bryla, 2007).

Both method and level of irrigation affected soil water content during the first 2 years after planting. Soil water content with drip was $2 \%$ higher than with sprinklers the first year (2004) and 5\% to $6 \%$ higher than with sprinklers and microsprays the second year (2005) (Table 2). Not surprisingly, soil water content was also higher with higher levels of water application, although more so the second season than the first, where it increased by $2 \%$ from $50 \%$ to $150 \% \mathrm{ET}_{\mathrm{c}}$ in 2004 and by greater than $6 \%$ in 2005 (Fig. 1). Drip is well known to maintain higher soil water availability within the root zone than other methods of irrigation (Kruse et al., 1990), thereby reducing water stress between irrigations and increasing plant growth and production (e.g., see Bryla et al., 2005); however, growth and production may be inhibited if saturated soil conditions persist (Davies and Wilcox, 1984). Soil was often saturated and exceeded field capacity (i.e., greater than $30 \%$ soil water content) in our study when irrigation was applied at $100 \%$ to $150 \% \mathrm{ET}_{\mathrm{c}}$ by drip and $150 \% \mathrm{ET}_{\mathrm{c}}$ by sprinklers and microsprays.

By the end of the first season (2004), plants irrigated by drip were larger and had significantly more new canes and higher fresh pruning weights than those irrigated by sprinkler, whereas those irrigated by microspray had an intermediate amount of each (Table 3 ). Visually, drip irrigation had clearly produced more plant growth the first year than either sprinklers or microsprays. However, this was not the case the next year. By late June 2005, plants irrigated by drip had significantly less canopy cover than those irrigated by sprinkler or microspray, a difference that continued to increase as the season progressed (Fig. 2). By July 2005 , many plants irrigated by drip began showing clear signs of root rot, including premature red and yellow leaves and stunted shoot growth. Similar symptoms were apparent in sprinkler and microspray treatments, but not nearly to the same extent as in drip. By the end of the second season, plants irrigated
Table 2. Effect of irrigation system on volumetric soil water content at 0 - to $0.3-\mathrm{m}$ depth in 2004 and 2005 .

\begin{tabular}{lcc}
\hline & \multicolumn{2}{c}{ Soil water content $(\%)$} \\
\cline { 2 - 3 } Irrigation system & 2004 & 2005 \\
\hline Sprinkler & $26.6 \mathrm{~b}^{\mathrm{z}}$ & $27.8 \mathrm{~b}$ \\
Microspray & $28.3 \mathrm{a}$ & $27.0 \mathrm{~b}$ \\
Drip & $29.0 \mathrm{a}$ & $32.7 \mathrm{a}$ \\
\hline
\end{tabular}

${ }^{z}$ Different letters within a column indicate a significance difference at $P=0.05$.

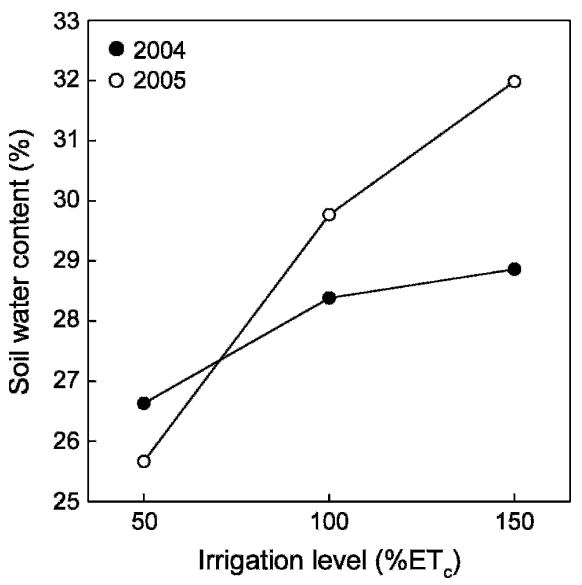

Fig. 1. Effect of irrigation level on volumetric soil water content at $0-0.3 \mathrm{~m}$ depth in 2004 and 2005 .

Table 3. Effect of irrigation system on new cane number and fresh pruning weight in 'Duke' blueberry in 2004 and 2005.

\begin{tabular}{llllll}
\hline Irrigation & \multicolumn{2}{c}{$\begin{array}{c}\text { New canes } \\
\text { (no./plant) }\end{array}$} & & \multicolumn{2}{c}{$\begin{array}{c}\text { Pruning } \\
\text { wt. (g/plant) }\end{array}$} \\
\cline { 2 - 3 } \cline { 5 - 6 } system & 2004 & 2005 & & 2004 & 2005 \\
\hline Sprinkler & $0.3 \mathrm{~b}^{\mathrm{z}}$ & $1.5 \mathrm{a}$ & & $26 \mathrm{c}$ & $76 \mathrm{a}$ \\
Microspray & $0.5 \mathrm{ab}$ & $1.5 \mathrm{a}$ & & $32 \mathrm{~b}$ & $80 \mathrm{a}$ \\
Drip & $0.7 \mathrm{a}$ & $1.0 \mathrm{~b}$ & & $37 \mathrm{a}$ & $50 \mathrm{~b}$ \\
\hline
\end{tabular}

${ }^{\mathrm{z}}$ Different letters within a column indicate a significance difference at $P=0.05$.

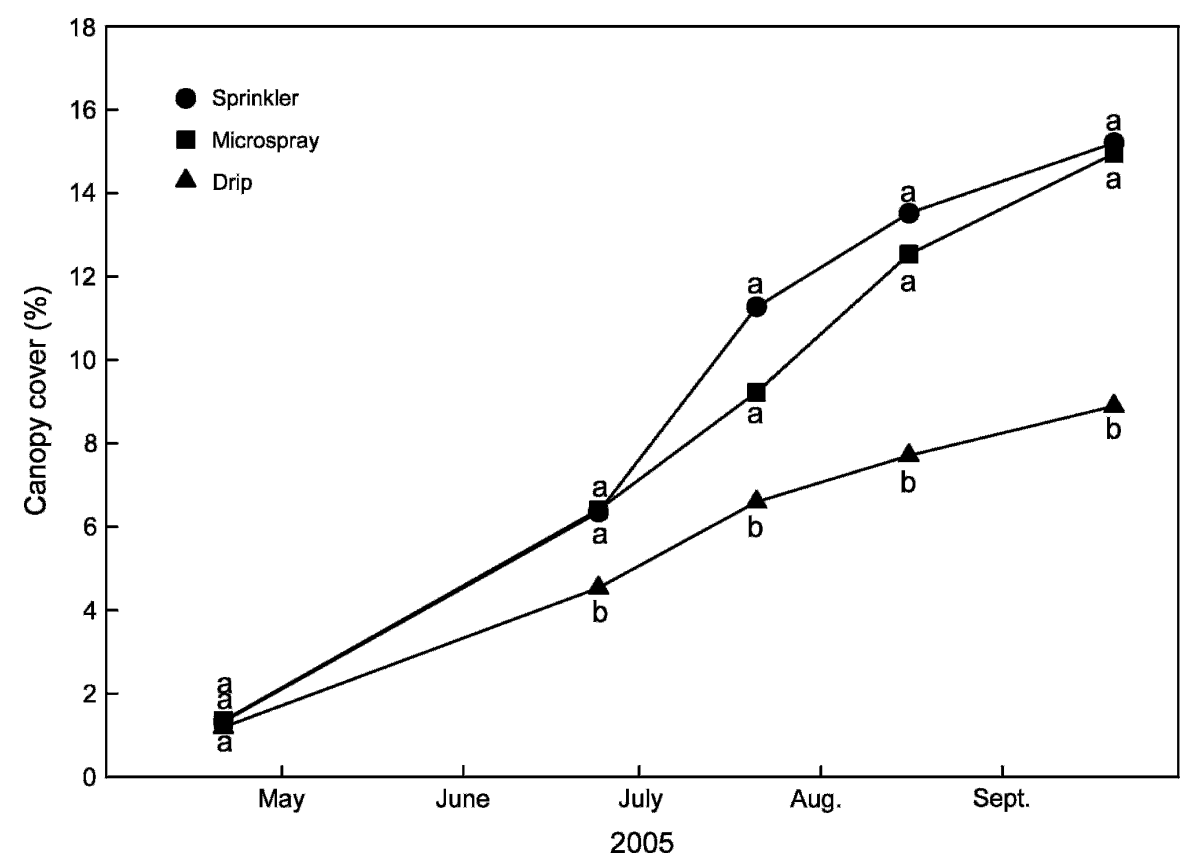

Fig. 2. Effect of irrigation system on canopy cover of 'Duke' blueberry in Apr. to Sept. 2005. Mean separation on each date by Duncan's multiple range test at $5 \%$ level. 
Table 4. Effect of irrigation system on plant dry weight, root system vigor, and root infection in 'Duke' blueberry in Oct. 2005.

\begin{tabular}{|c|c|c|c|c|c|}
\hline \multirow[b]{2}{*}{ Irrigation system } & \multicolumn{2}{|c|}{ Plant dry wt (kg) } & \multirow[b]{2}{*}{ Root system vigor ${ }^{y}$} & \multicolumn{2}{|c|}{ Infected roots $(\%)^{x}$} \\
\hline & Shoot & $\operatorname{Root}^{2}$ & & $\overline{\mathrm{P}_{5} \mathrm{ARP}}$ & $\mathrm{P}_{5} \mathrm{ARP}+\mathrm{H}$ \\
\hline Microspray & $0.131 \mathrm{a}$ & $0.113 \mathrm{a}$ & $3.0 \mathrm{a}$ & 19.8 & $7.3 \mathrm{~b}$ \\
\hline Drip & $0.062 \mathrm{~b}$ & $0.060 \mathrm{~b}$ & $1.8 \mathrm{~b}$ & 29.1 & $14.3 \mathrm{a}$ \\
\hline
\end{tabular}

${ }^{\mathrm{z}}$ Includes crown.

${ }^{\mathrm{y}}$ See Materials and Methods for root system vigor ratings.

${ }^{x}$ Roots were plated on $\mathrm{P}_{5} \mathrm{ARP}$ media selective for members of the Pythiaceae family and $\mathrm{P}_{5} \mathrm{ARP}+\mathrm{H}$ agar media selective for Phytophthora spp.

wIrrigation system had no effect on percentage of infected roots on $\mathrm{P}_{5} \mathrm{ARP}(P=0.14)$.

${ }^{\vee}$ Different letters within a column indicate a significance difference at $P=0.05$.

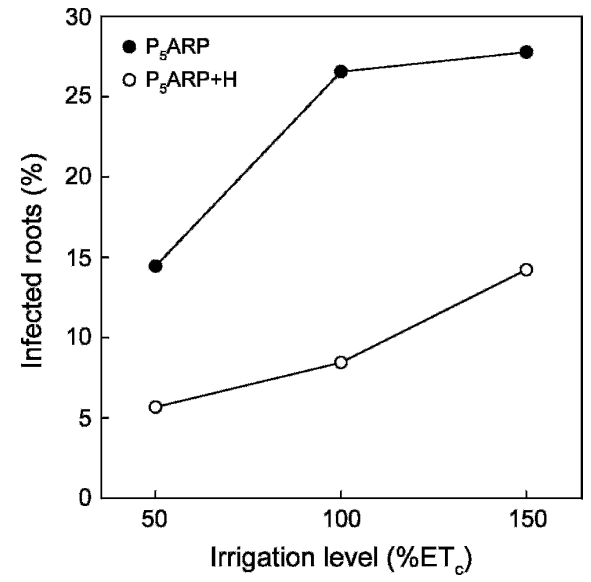

Fig. 3. Effect of irrigation level on root infection of 'Duke' blueberry in Oct. 2005. Roots were plated on $\mathrm{P}_{5} \mathrm{ARP}$ media selective for members of the Pythiaceae family and $\mathrm{P}_{5} \mathrm{ARP}+\mathrm{H}$ media selective for Phytophthora spp.

by drip had only half as much canopy cover as plants irrigated by sprinkler and microspray (Fig. 2) and produced fewer canes and less pruning weight (Table 3 ).

Destructive sampling in Oct. 2005 revealed that plants irrigated by drip had lower shoot and root dry weights, less root system vigor, and a higher percentage of infected roots (although not significantly higher on $\mathrm{P}_{5} \mathrm{ARP}$ media) than plants irrigated by sprinkler or microspray (Table 4). Root infection was also affected by irrigation level, increasing by $13 \%$ on $\mathrm{P}_{5} \mathrm{ARP}$ and $9 \%$ on $\mathrm{P}_{5} \mathrm{ARP}+\mathrm{H}$ from $50 \%$ to $150 \% \mathrm{ET}_{\mathrm{c}}$ (Fig. 3). Regression analysis revealed that $90 \%$ to $93 \%$ of the variation in root, shoot, and total plant dry weight was explained by the linear function of root system vigor (Fig. 4A), whereas $70 \%$ of the variation in root system vigor was accounted for by the linear function of root infection on $\mathrm{P}_{5} \mathrm{ARP}+\mathrm{H}$ (Fig. 4B). Root vigor was not related to root infection on $\mathrm{P}_{5} \mathrm{ARP}$ however $(P=\approx 0.06$; Fig. $4 \mathrm{~B})$. Isolates growing on $\mathrm{P}_{5} \mathrm{ARP}$ were identified as Pythium spp., whereas those on $\mathrm{P}_{5} \mathrm{ARP}+\mathrm{H}$ were identified as $P$. cinnamomi.

Neither irrigation water nor plant-free soil samples collected near the plants had any detectable level of Phytophthora or Pythium. Although these pathogens can survive for several years in soil in the absence of a host (Zentmyer and Mircetich, 1966), the field was previously planted with rye grass and vetch and never planted before with blue-
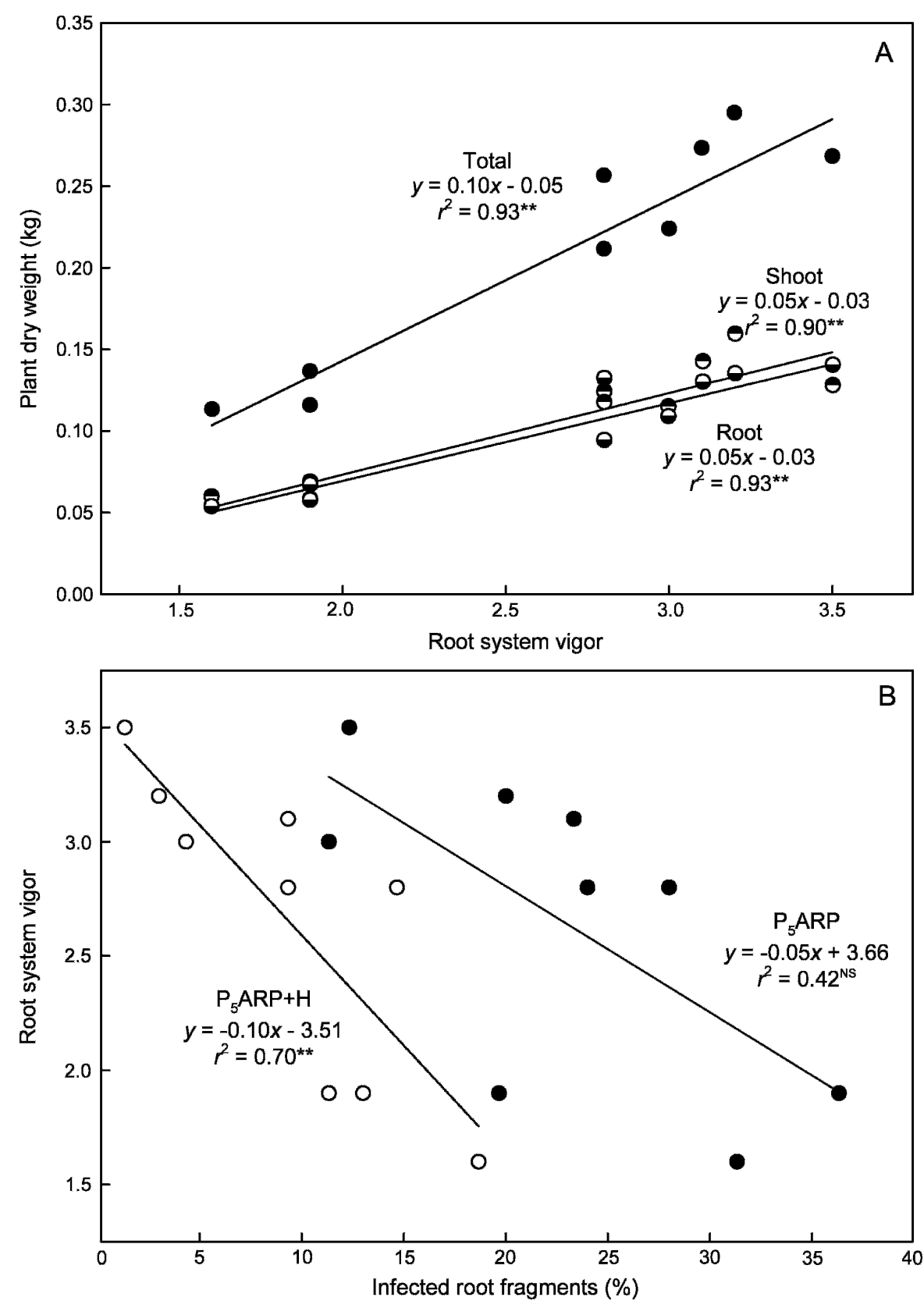

Fig. 4. Relationships between (A) shoot, root, and total plant dry weight and root system vigor and (B) root system vigor and root infection on $\mathrm{P}_{5} \mathrm{ARP}$ and $\mathrm{P}_{5} \mathrm{ARP}+\mathrm{H}$ media in 'Duke' blueberry. Data were obtained from plants irrigated at 50,100 , and $150 \% \mathrm{ET}_{\mathrm{c}}$ by sprinklers, microsprays, or drip. NS $=$ nonsignificant; $* * P<0.01 . \mathrm{ET}_{\mathrm{c}}=$ estimated crop evapotranspiration.

berry, making it unlikely that $P$. cinnamomi or many of the Pythium spp. observed were already present in the field before planting. It is also unlikely that irrigation water was a source of inoculum, because the well from which the water was pumped was put online only a few months before the study was started. Thus, any Phytophthora and Pythium 
spp. infecting the roots probably originated with the planting stock. It should not be discounted, however, that 'Duke' is highly susceptible to root rot and therefore could develop infection with even small amounts of inoculum, including amounts not detected during our soil and well water testing. In a recent survey of commercial fields in Oregon, P. cinnamomi was found more frequently in 'Duke' than in many other cultivars, occurring in $36 \%$ of 14 fields of 'Duke' sampled, whereas Pythium was equally abundant in every cultivar (11 total), occurring in $85 \%$ of the total 55 fields sampled (Bryla et al., unpublished results).

Drip irrigation likely increased root rot in our study because it maintained higher soil water contents and therefore higher matric potentials in the root zone than sprinklers or microsprays, creating conditions more favorable to infection. Release of zoospores from sporangia in Phytophthora species is extremely sensitive to small changes in soil matric potential and occurs predominately at values between 0 and $-1.0 \mathrm{kPa}$ (Duniway, 1979). Ownley and Benson (1991) found that infection by $P$. cinnamomi in Rhododendron spp. was significantly less in plants grown in pine bark than in those grown in a mix of peat, sand, and soil. The pine bark media had volumetric air-filled porosities that fluctuated from $\approx 40 \%$ just after irrigation to $45 \% 48 \mathrm{~h}$ later and matric potentials that fluctuated from -1.0 to $-3.0 \mathrm{kPa}$, whereas the peat/ sand/soil mix fluctuated between porosities of $10 \%$ to $20 \%$ and matric potentials of 0 to $-1.0 \mathrm{kPa}$. They concluded that pine bark drained more quickly and completely than the mix, resulting in matric potentials unfavorable to zoospore discharge and dispersal. Good irrigation practices have a similar effect on soil matric potential and are essential to reduction of the effects of root rot in citrus [Citrus sinensis (L.) Osbeck] (Feld et al., 1990); however, in this later case, drip irrigation of mature trees reduced spread of the disease relative to furrow irrigation by reducing movement of zoospores.

In summary, the results indicate that sites prone to root rot such as those with heavy soil, poor drainage, or a history of the disease may be less suited to drip and better suited to sprinkler and microspray systems. These later systems may also lower the risk of developing infection when irrigation is overapplied. However, because drip is already predominately used in many regions of the United States, including Arkansas, California, Indiana, Minnesota, Mississippi, New York, and Washington, as well as in Canada, Mexico, and South America (Bañados, 2006; Strik and Yarborough, 2005), further study is required to identify practices such as different lateral placements or more appropriate irrigation frequencies that reduce conditions that favor root rot when using drip.

\section{Literature Cited}

Bañados, M.P. 2006. Blueberry production in South America. Acta Hort. 715:165-172.

Berhardt, E.A. and R.G. Grogan. 1982. Effect of soil matric potential on the formation and indirect germination of sporangia of Phytophthora parasitica, $P$. capsici, and $P$. cryptogea. Phytopathology 72:507-511.

Brannen, P.M. and S. NeSmith. 2006. Fungicidal control of Pythium root rot of blueberry in high-density bark bed planting, 2005. F \& N Tests 61:SMF016.

Bryla, D.R. 2007. Water requirements of young blueberry plants irrigated by sprinklers, microsprays, and drip. Acta Hort. (In press).

Bryla, D.R., E. Dickson, R. Shenk, R.S. Johnson, C.H. Crisosto, and T.J. Trout. 2005. Influence of irrigation method and scheduling on patterns of soil and tree water status and its relation to yield and fruit quality in peach. HortScience 40:2118-2124.

Bryla, D.R. and B.C. Strik. 2007. Effects of cultivar and plant spacing on the seasonal water requirements of highbush blueberry. J. Amer. Soc. Hort. Sci. 132:270-277.

Café-Filho, A.C. and J.M. Duniway. 1995. Effects of furrow irrigation schedules and host genotype on Phytophthora root rot of pepper. Plant Dis. 79:39-43.

Café-Filho, A.C. and J.M. Duniway. 1996. Effects of location of drip irrigation emitters and position of Phytophthora capsici infections in roots on Phytophthora root rot of pepper. Phytopathology 86:1364-1369.

Café-Filho, A.C., J.M. Duniway, and R.M. Davis. 1995. Effects of frequency of furrow irrigation on root and fruit rots of squash caused by Phytophthora capsici. Plant Dis. 79:44-48.

Caruso, F.L. and D.C. Ramsdell. 1995. Compendium of blueberry and cranberry diseases. APS Press, St. Paul, MN.

Cline, W.O. and A. Schilder. 2006. Identification and control of blueberry diseases, p. 115-138. In: Childers, N.F. and P.M. Lyrene (eds.). Blueberries. For growers, gardeners, promoters. Dr. Norman F. Childers Hort. Publ., Gainesville, FL.

Davies, F.S. and D. Wilcox. 1984. Waterlogging of containerized rabbiteye blueberries in Florida. J. Amer. Soc. Hort. Sci. 109:520-524.

de Silva, A., K. Patterson, C. Rothrock, and R. McNew. 1999. Phytophthora root rot of blueberry increases with frequency of flooding. HortScience 34:693-695.

Duniway, J.M. 1979. Water relations of water molds. Ann. Rev. Phytopathol. 17:431-460.

Duniway, J.M. 1983. Role of physical factors in the development of Phytophthora diseases, p. 175187. In: Erwin, D.C., S. Bartnicki-Garcia, and P.H. Hsiao (eds.). Phytophthora: Its biology, taxonomy, ecology, and pathology. Am. Phytopath. Soc., St. Paul, MN.

Feld, S.J., J.A. Menge, and L.H. Stolzy. 1990 Influence of drip and furrow irrigation on Phytophthora root rot of citrus under field and greenhouse conditions. Plant Dis. 74:21-27.

Gomez, K.A. and A.A. Gomez. 1984. Statistical procedures for agricultural research. 2nd ed. Wiley, New York.

Holzapfel, E.A., R.F. Hepp, and M.A. Marino. 2004. Effect of irrigation on fruit production in blueberry. Agr. Water Mgt. 67:173-184.

Kannwischer, M.E. and D.J. Mitchell. 1978. The influence of a fungicide on the epidemiology of black shank of tobacco. Phytopathology 68:1760-1765.

Kruse, E.G., D.A. Bucks, and R.D. von Bernuth 1990. Comparison of irrigation systems, p. 475-508. In: Steward B.A. and D.R. Nielsen (eds.). Irrigation of agricultural crops. ASACSA-SSSA Publ. Agron. Monogr. 30.

Larkin, R.P., M.L. Gumpertz, and J.B. Ristaino. 1995. Geostatistical analysis of Phytophthora epidemics in commercial bell pepper fields. Phytopathology 85:1057-1063.

Masago, H., M. Yoshikawa, M. Fukada, and N. Nakanishi. 1977. Selective inhibition of Pythium spp. on a medium for direct isolation of Phytophthora spp. from soils and plants. Phytopathology 67:425-428.

Ownley, B.H. and D.M. Benson. 1991. Relationship of matric water potential and air-filled porosity of container media to development of Phytophthora root rot of rhododendron. Phytopathology 81:936-941.

Patten, K.D., E.W. Neuendorff, G.H. Nimr, S.C. Peters, and D.L. Cawthon. 1989. Growth and yield of rabbiteye blueberry as affected by orchard floor management practices and irrigation geometry. J. Amer. Soc. Hort. Sci. 114:728-732.

Ristaino, J.B. 1991. Influence of rainfall, drip irrigation, and inoculum density on the development of Phytophthora root and crown rot epidemics and yield in bell pepper. Phytopathology 81:922-929.

Ristaino, J.B., J.M. Duniway, and J.J. Marois. 1988. Influence of frequency and duration of furrow irrigation on the development of Phytophthora root rot and yield in processing tomatoes. Phytopathology 78:1701-1706.

Ristaino, J.B. and S.A. Johnson. 1999. Ecologically based approaches to management of Phytophthora blight on bell pepper. Plant Dis. 83:10801089.

Ristaino, J.B., R.P. Larkin, and C.L. Campbell. 1993. Spatial and temporal dynamics of Phytophthora epidemics in commercial bell pepper fields. Phytopathology 83:1312-1320.

Rotem, J. and J. Palti. 1969. Irrigation and plant diseases. Ann. Rev. Phytopathol. 7:267-288.

Schlub, R.L. 1983. Epidemiology of Phytophthora capsici on bell pepper. J. Agr. Sci. (Camb.) 100:7-11.

Stamps, D.J., G.M. Waterhouse, F.J. Newhook, and G.S. Hall. 1990. Revised tabular key to the species of Phytophthora. CAB International Mycological Institute, Mycol. Pap. 162.

Sterne, R.E., G.A. Zentmyer, and M.R. Kaufman. 1977a. The effect of matric and osmotic of soil on phytophthora root rot disease of Persea indica. Phytopathology 67:1491-1494.

Sterne, R.E., G.A. Zentmyer, and M.R. Kaufman. 1977b. The influence of matric potential, soil texture, and soil amendment on root disease caused by Phytophthora cinnamomi. Phytopathology 67:1495-1500.

Strik, B.C. and D. Yarborough. 2005. Blueberry production trends in North America, 1992 to 2003 and predictions for growth. HortTechnology 15:391-398.

Utkhede, R.S. and E.M. Smith. 1996. The effect of three irrigation practices on phytophthora crown and root rot of apple trees under field conditions. Eur. J. Plant Pathol. 102:507-510.

Zentmyer, G.A. and S.M. Mircetich. 1966. Saprophytism and persistence in soil by Phytophthora cinnamomi. Phytopathology 56:710-712. 